\title{
VINDICATING SCIENCE AND HUMAN RIGHTS THROUGH THE COURTS
}

\author{
Brian Honermann, $J D$ \\ AIDS Law Project, Johannesburg
}

\begin{abstract}
South African Security Forces Union and Others v. Surgeon General and Others. ${ }^{1}$ This case challenged the South African National Defence Force's health classification policy, which for years has prevented recruits and soldiers with HIV from recruitment, external deployment or promotion within the SANDF regardless of their actual state of health or the area of work for which they would be responsible. Along with the Union, the individual applicants in the case were a potential recruit who had applied to join the Air Force band as a trumpeter, a soldier who conducts combat readiness preparation for deploying troops, and an administrative personnel clerk. Respectively, these three applicants had been denied recruitment, foreign deployment and promotion in the SANDF solely on the basis of their HIV status.
\end{abstract}

On 19 May 1994, the AIDS Law Project wrote a letter to the Minister of Defence questioning the constitutionality of the SANDF policy of excluding individuals from recruitment into the SANDF solely on the basis of their HIV status. In a letter dated 22 July the Deputy Minister of Defence at the time, Ronnie Kasrils, responded:

The National Defence Force, like any employer, is duty bound to ensure that the persons it employs are physically and mentally suited to the rigorous training and utilization which is demanded from military practitioners. ... [T]he policy regarding serological screening and the exclusion from employment of HIV positive applicants [cannot] be described as an 'unfair discrimination' against them, considering the potentially dangerous and clearly rigorous nature of military service and training.

This position of the SANDF was maintained throughout the ensuing 14 years, despite significant scientific and legal advances in the understanding and treatment of HIV disease. These advances included the development of highly active antiretroviral therapy (HAART), the free provision of antiretroviral (ARV) treatment in the South African public health sector, and a series of superior court judgments dealing with unfair discrimination in the workplace. On 16 May 2008, however, that unjustifiable policy formally came to an end when the SANDF finally conceded in open court that the policy was unconstitutional.

While this is a delayed victory, it is still important - not just for those living with HIV in South Africa, but also internationally. This case is now part of a growing series of cases from Australia, Canada, Mexico and Namibia that have vindicated the rights of people living with HIV to seek jobs in and be employed by the military. These policies have for too long been a constant reminder that, while the governments of the world stress the human rights of people living with HIV and the importance of destigmatising HIV status, they have at the same time been creating and applying policies that disregard scientific evidence, continue to promote the perception that HIV status is relevant to employment, and, ultimately, increase the stigma and discrimination suffered by those individuals they claim to be supporting.

As with Hoffman v. South African Airways ${ }^{2}$ and other cases of unfair discrimination, ${ }^{3,4}$ this case was won (and lost) on the scientific evidence put before the court. Enforcement of the constitutional rights of individuals relies on the best evidence being made available to dispute, reveal, and discourage governments, employers, and individuals from continuing policies unfounded by scientific evidence or reasoning.

\section{SCIENTIFIC EVIDENCE}

While there is a recognised dearth of good-quality research evaluating the performance capabilities of HIVpositive individuals in military environments, largely owing to the discriminatory policies of the militaries themselves, the applicants in the South African Security Forces Union (SASFU) case offered the testimony of six different medical experts - collectively comprising more then 1000 pages of the court record and citations to over 65 different medical studies, workplace policies and international guidelines - on the science and treatment of HIV and its impact (or lack thereof) on the capacity of HIV-positive individuals to perform in a military environment. Experts included Dr Brian Brink, Professor Trefor Jenkins, Professor Leslie London, Dr Shuaib Manjra, Dr Robert Schooley and Dr Francois Venter. Their affidavits can be found on the AIDS Law Project website. $^{5}$ 
Along with the scientific evidence of Dr Francois Venter and Professor Leslie London regarding HIV disease progression and ARV therapy (ART), the SANDF's justification that HIV-positive individuals were incapable of surviving military environments was questioned by multiple sources. Dr Brian Brink provided testimony regarding the proven benefits of Anglo-American's HIV prevention, treatment and support programmes in the mining sector. Despite the physically and mentally harsh work environment and need to operate heavy machinery, access to ARV treatment and other comprehensive health care services has enabled HIV-positive miners to continue in their work alongside their HIV-negative counterparts (affidavit of Dr Brian Brink ${ }^{5}$ ).

Relying on several studies (including Terry et al. ${ }^{6}$ Rigsby et al., ${ }^{7}$ Nixon et al. ${ }^{8}$ and O'Brien et al. ${ }^{9}$ ), Dr Shuaib Manjra testified that moderate- and high-intensity physical training has been shown to have no negative effects on HIV-positive individuals and is probably beneficial to the immune system. HIV-positive professional and amateur athletes including Magic Johnson (former professional basketball player and Olympic gold medalist), Rudy Galindo (former US ice figure skating champion), Greg Louganis (five-time Olympic medallist in diving), Rob McCall (ice dancing Olympic bronze medallist), Roy Simmons (former New York Giants football player) and Evelina Tshabalala (twotime Comrades marathon runner, who also successfully climbed Mount Aconcagua) have continued to perform at top levels of physical performance in stressful situations and harsh physical environments.

In the face of this expert testimony, the SANDF relied almost exclusively on a single 'medical study' supposedly conducted in the Zimbabwean military which was undated, unpublished and revealed a complete ignorance of both medical science and medical ethics. In its own words, the study '[sought] to prove the hypothesis that the type, intensity, frequency and duration of exercise' in a military environment will lead to 'opportunistic infection[s] and an early onset of [full-blown AIDS] among HIV-seropositives'. In other words, the study's stated goal was to subject people with HIV to conditions directly harmful to their health to assess their capacity to survive. This goal is contrary to even the most basic understanding of medical ethics, which stands and falls on the principle of 'do no harm', and is underscored by the fact that 6 HIV-positive participants died as a result.

Professor London's exhaustive analysis of the study (affidavit of Professor London ${ }^{5}$ ) revealed that 'the study has so many weaknesses that it could not be considered to have produced valid findings. There are errors in the methodology, the data collection, the data analysis and presentation, and in the interpretation of the findings'. The errors were so flagrant that it 'warrant[s] a concern that the study may have been entirely fabricated.'

On ethical grounds, London argued that the fact that the study made no statement as to whether ART was made available to participants invalidates its relevance and raises echoes of the Tuskegee study perpetrated on African-American men in the USA. The Tuskegee study is infamous for enrolling participants with syphilis into a 'medical study' and then preventing them from receiving treatment in order to map the progression of the disease. Some of those denied treatment were active US soldiers in World War II. More than 100 participants died during the Tuskegee study. The Zimbabwean study, if done without access to ART, was inapplicable to the SANDF, where such treatment has been available since 2004 . More worrying is the possibility that ART was available to the HIV-positive participants, but was deliberately withheld in order to track their declining health. If this is the case, it is a gross violation of medical ethics.

In his affidavit, ${ }^{5}$ Professor Trefor Jenkins pointed out that the study's basic conceptualisation was to determine the level of physical extremes to which the human body may be subjected. It 'may be considered ... similar to some of those conducted by Nazi doctors during the Second World War. It is akin to thawing people after they have been frozen in order to see what temperatures the human body can withstand. Those are his words. Comparisons of this nature are not made lightly by academics against their colleagues.

\section{LEGAL IMPLICATIONS}

The Constitution sets a high standard for respect of human rights by all parts of the government, including the SANDF. This requires more affirmative involvement and scrutiny on the part of Cabinet Ministers, Members of Parliament, heads of departments and other decisionmakers, to ensure that they constantly review their policies in the face of the advancement of medical science. Government is not permitted by the Constitution to hold back and await challenges to its policies, either in the courts or from civil society mobilisation, before taking recognition of new developments. Rather, it is under an obligation to 'respect, protect, promote and fulfil the rights in the Bill of Rights', including the right to equality (Constitution, section 7(2)). Passivity is insufficient and its defence is unjustifiable. In the case of the SANDF, the spurious defence put forward in court, based on a study which was almost certainly performed in violation of the human rights of its participants, is both morally and constitutionally repugnant. For the South African government to rely on the results of flagrant human rights abuses to justify its own unconstitutional conduct legitimises such abuses, whether in the past or the future, whether at home or abroad. Properly conducted medical science requires careful analysis and respect for the people involved, neither of which is shown here. In addition, the delay in implementing a new policy since the 16 May 2008 court order continues a violation of the rights to equality and dignity of those who still seek to advance their careers in the SANDF. (In this regard, the AIDS Law Project in September and October 2008

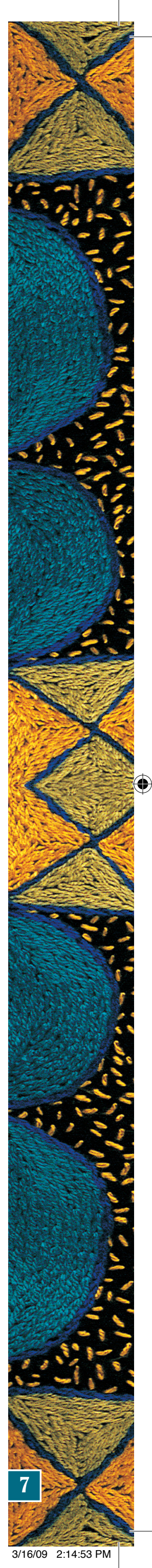


collected affidavits from soldiers in several infantry battalions who were continuing to be excluded from consideration for foreign deployments due solely to their HIV status.)

Once again, here, the failure of high-level SANDF officials to critically evaluate their own 'evidence' has undermined respect for human rights. An unethical study continues to be unethical regardless of who commissioned it, who conducted it or who brought it to their attention. This was lost on the Surgeon-General, whose response to the critiques summarised above was that 'the SANDF did not commission or participate in the Zimbabwean Study. Instead our attention was drawn to the study by Dr [Martin] Rupiya'. (Dr Rupiya was formerly with the Institute for Security Studies and the author of The Enemy Within: Southern African Militaries' Quarter-Century Battle with HIV and AIDS. He offered expert testimony for the SANDF in which the Zimbabwean study was introduced into evidence.) This is a wholly inadequate response, not least because it continues to willfully ignore the study's basic scientific failures. As Professor London stated, 'It is disturbing that the affidavits of [Surgeon-General] Ramlakan, [Brigadier General] Dhlomo and [Trevor Lewis] Reynolds rely on a study with such methodological, statistical, and ethical problems, without exercising a modicum of critical assessment of the quality of the study. Critical appraisal of research is a standard competency our medical and other health professional students are expected to achieve [in order to] distinguish good quality evidence from poor research [not fit] for clinical decision-making or policy development.'

There is already a long and shameful history of denying the integrity of medical science within certain elements of government, particularly as it relates to HIV. So far, litigation has unfortunately been a necessary means of imposing rationality on government policies which are meant to be based on the best available evidence. It was necessary first to get pregnant women access to services to prevent mother-to-child transmission of HIV. ${ }^{10}$ It was necessary to compel the Department of Health to take action against Matthias Rath for numerous violations of medicines law, including unauthorised and unethical clinical trials. ${ }^{11}$ It has been necessary to get prisoners access to lifesaving medical care. ${ }^{12}$ This case is yet another unacceptable example where the government has chosen to fight for the continued stigmatisation and inequality of people living with HIV, rather than on the side of the Constitution.

While the courts have largely responded well to these challenges, as the country heads for elections, it is important that the principles of human rights, which are affirmed and supported through rational thought and scientific evidence, become part of the national dialogue and that the constitutional vision of respect for fundamental human rights does not remain in the domain of the courts or out of reach of those with little access to the legal system, but becomes infused into how government administrators and decision-makers approach their work. The principles of respect for science and respect for a progressive Constitution have been laid by the courts, but without political will those principles will remain little more than pieces of paper referring to a document whose promise requires far more.

REFERENCES
South African Security Forces Union and Others v Surgeon General and Others. Case No. $18683 / 07$ (TPD).
Hoffman v South African Airways [2000] ZACC 17.
3. IMATU v City of Cape Town [2005] 26 IL 1404 (LC)
4. 'A'v South African Airways (Pty) Ltd. Case No. J1916/99.
5. AIDS Law Project website. http://www.alp.org.za/index.php?option=com_content Etask=viewEtid=43\&tltemid=8 (accessed 20 February 2009).
6. Terry et al. Moderate and high intensity exercise training in HIV-1 seropositive individuals: a randomized trial. Int J Sports Med 1999; 20: 142-146.
7. Rigsby et al. Effects of exercise training on men seropositive for the human immunodeficiency virus-1. Med Sci Sports Exerc 1992 (24).
8. Nixon et al. Aerobic exercise interventions for adults living with HIV/AIDS. Cochrane Database Systematic Reviews 2005, issue 2.
9. O'Brien et al. Progressive resistance exercise interventions for adults with HIV/AIDS. Cochrane Database Systematic Reviews 2004, issue 4.
10. Minister of Health and Others v Treatment Action Campaign and Others (no 2) [2002] ZACC 15.
11. Treatment Action Campaign and Another v Rath and Others [2008] ZAWCHC 34.

12. EN and Others $v$ Government of the RSA and Others [2007] 1 All SA 74 (D).

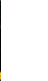

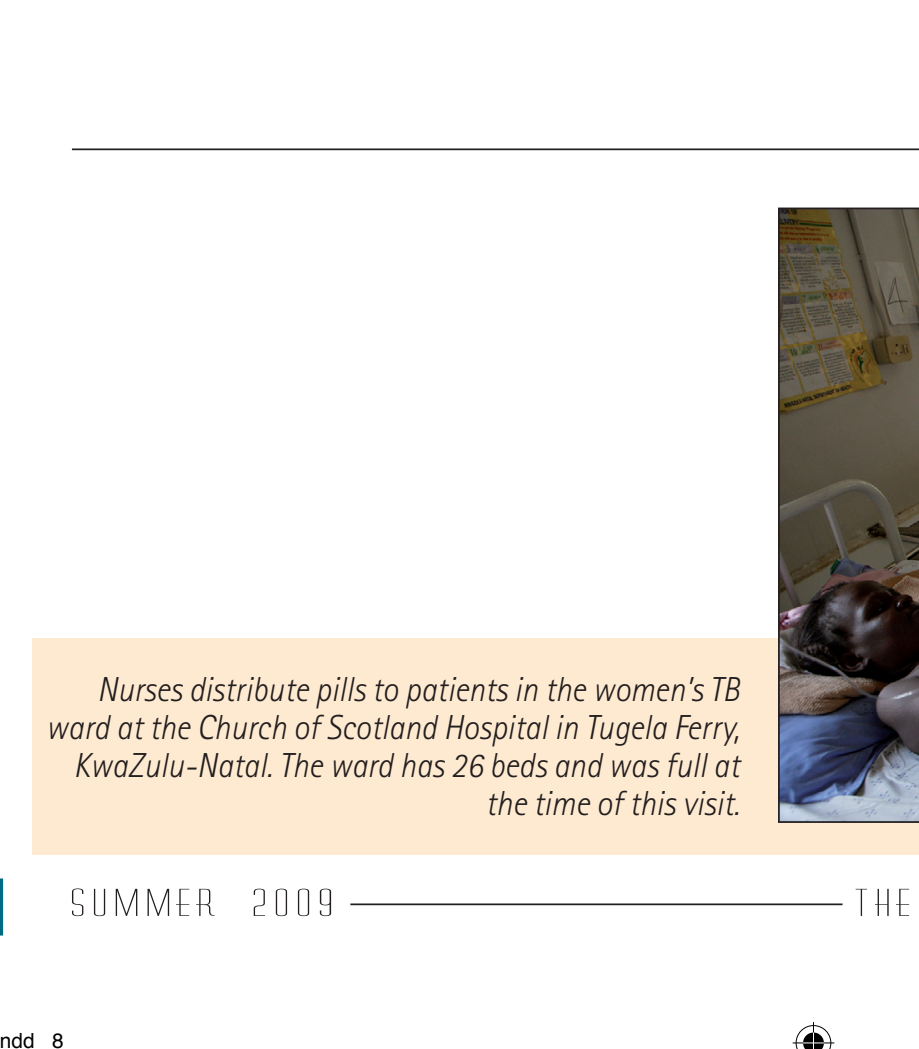

Nurses distribute pills to patients in the women's TB ward at the Church of Scotland Hospital in Tugela Ferry, KwaZulu-Natal. The ward has 26 beds and was full at the time of this visit

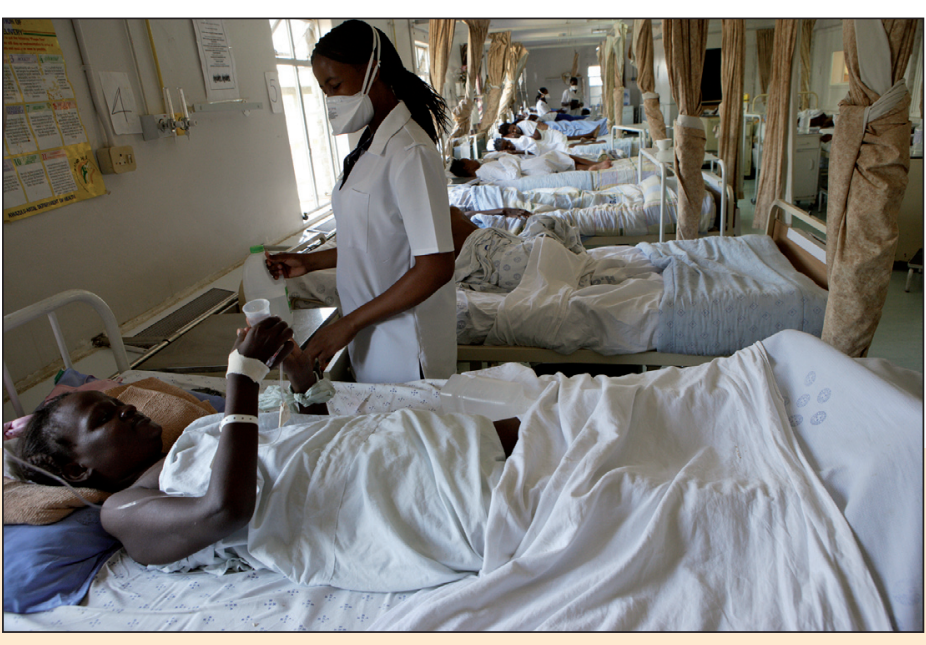
THE SOUTHERN AFrICAN JOURNAL OF HIV MEDICINE 